\title{
AZ ELEKTRONIKUSSZOLGÁLTATÁS- MINŐSÉG ÉRTÉKELÉSE A PÉNZÜGYI SZOLGÁLTATÁSOK ONLINE VÁSÁRLÁSA ESETÉBEN
}

Az elektronikus kiskereskedelem fejlódése az elmúlt években töretlen, és ennek köszönhetóen számos izgalmas kutatási terület jelenik meg évról évre. Ebben a folyamatosan változó környezetben a vásárlási döntési folyamat, valamint a vásárlás utáni interakciók megértése nem egyszerú feladat. Jelen tanulmány célja kettős. A szerző először megvizsgálja az e-kereskedelemhez köthető elektronikusszolgáltatás-minőség értelmezését a pénzügyi szolgáltatások esetében, majd egy primer kutatás során bemutatja a minőségészlelés, az elégedettség és annak következményeinek alakulását és összefüggéseit három, konkrét, online pénzügyi vásárlás esetében, úgymint az e-bankolás, az online tőzsdézés, illetve a biztosítások online kötése. A kutatás végén a minőségészlelés alapján négy vásárlói szegmenst azonosít, és viselkedésüket górcsố alá veszi, mely eredmények a vállalati stratégiaalkotás folyamatában nyújthatnak segítséget.

A probléma részletes megismerése érdekében elsôként a szakirodalomban megjelenó elméleteket járja körbe, melyet primer kutatási eredményeivel is kiegészít, hogy ezzel is részletesebben megismerhetó legyen a hazai kép. ${ }^{1}$

\section{Kulcsszavak: pénzügyi szolgáltatások, e-kiskereskedelem, elektronikusszolgáltatás-minőség, PLS-SEM}

A vállalatok értékesítési folyamatában az internet kiemelkedő szerepet játszik napjainkban az információgyuujtési szakasz támogatásától egészen a vásárlásig, a rendelések utánkövetéséig, vagy akár az elektronikus termékek, szolgáltatások igénybevételéig (pl. szoftverek, e-bankolás). Az online környezet a hagyományos, offline üzletek mellett egy alternatív megoldást jelenthet az értékesítésben (pl. bevasarlas.tesco.hu), vagy akár egy kiterjesztett, időtakarékos megoldásként (pl. e-bankolás) is szolgálhat. Ezzel szemben a vásárlók számára az internet egy közel tökéletes piacot jelent, hisz az információk és árak azonnal elérhetők, és ezeket az egyének világszerte össze tudják hasonlítani.

Azonban fontos kiemelni, hogy ugyanazon szolgáltatás igénybevétele során az online és offline környezet különböző élményt nyújthat a vásárlók számára. Az online megoldások kényelmet kínálnak időben és helyben, azonban hiányoznak az offline környezetben jelenlévô személyes interakciók (Wolfinbarger - Gilly, 2003). Az online vásárlás, illetve szolgáltatás-igénybevétel inkább magányos, tervszerú folyamat, mintsem szociálisan interaktív esemény.
Az online vásárlást azonban nem érdemes egy homogén területként kezelni, mivel a kielégítendő igényektől és az offline is elérhetô kiegészítő-szolgáltatásoktól függően a felhasználók elvárásai különbözhetnek. Csoportképző ismérvnek lehet tekinteni a vásárolt és/vagy igénybevett jószág jellegét, a vállalat internethasználati szokásait (tiszta online vagy vegyes online jelenlét), az alkalmazott modellt (pl. Groupon-modell), és az ezek alapján meghatározott szegmensekben érdemes a különböző mechanizmusok múködését elkülönítetten vizsgálni. Francis és White 2003-ban alkották meg az e-kereskedelemi tevékenységek marketingközpontú kategorizálását, melynek során a vásárolt jószág jellege, valamint az igénybevétel módja (offline vagy online) alapján négy szegmenst azonosítottak: az offline termékek, az elektronikus termékek, az offline szolgáltatások és az elektronikus szolgáltatások piacát.

Jelen tanulmány elméleti fókuszában az elektronikus szolgáltatásokhoz, vagyis az online vásárolt és online igénybe is vett szolgáltatásokhoz kapcsolódó minőségészlelés témakörének vizsgálata áll, míg primer kutatásunkkal egy szúkebb területet, az online pénz- 
ügyi szolgáltatások vásárlását szeretnénk részletesen körbejárni.

\section{A minőség szerepe a vállalati múködésben}

A minőség az elégedettség kialakulásának egyik alappillére (Wolfinbarger - Gilly, 2003), ezáltal a hoszszú távú sikeres teljesítés (Fassnacht - Koese, 2006; Santos, 2003; Zeithaml et al., 2002; Ladhari, 2010) és versenyképesség (Bressolles - Nantel, 2006) egy kiemelt tényezője. Az online vásárlók sokkal több ajánlat közül válogathatnak, így az új ügyfelek megszerzése nehezebb és költségesebb folyamat, mint az offline közegben (Fu-Ling - Chuan, 2012; Christodoulides - Michaelidou, 2011). Reichheld és Schefter (2000) szerint online környezetben az új ügyfelek meggyőzése 20-40\%-kal többe kerül, mint a hagyományos, offline piacon.

Az elégedett, visszatérő vásárlók számának növekedésével csökkenhetnek a vállalat marketingköltségei, egyszerúbben zajlanak le a tranzakciók, és ez segít a versenyben is jobban helytállni (Liu - Arnett, 2000). Ezek a vásárlók a vállalati kommunikációt „önkéntesen" támogatva nagyobb valószínúséggel ajánlják az üzletet másoknak (Gefen, 2002), könnyebben megértik és elfogadják, ha valamilyen probléma merül fel, és bizonyos esetekben az igénybevett termékért/szolgáltatásért hajlandóbbak magasabb árat is fizetni (Reichheld - Schefter, 2000; Gefen, 2002). A vállalatok szempontjából további pozitív hozadék, hogy a visszatérő vásárlókat - mivel már ismerik az elvárásaikat - könnyebben elégedetté tudják tenni (Zeithaml et al., 1996; Demeter, 2009), ami a vállalat vevókapcsolati tókéjét is erősíti.

\section{Az e-kereskedelem csoportosítása}

Adam (2002) szerint a vállalatok internetes használati szokásai a kereskedelem területén a tiszta (pure) offline és a tiszta (pure) online kontinuumban mozognak, melynek középpontját a „clicks-and-bricks” boltok adják. Mások az e-kereskedelem sajátosságait a szállítás módjában látják: szerintük célszerú eltéró fókusszal vizsgálni a postán vagy a futárral szállítókat, illetve azokat, akik elektronikusan szállítanak (Francis - White, 2002; Wolfinbarger - Gilly, 2003). A vásárlások csoportosítása a szállítás módja alapján egy jó marketingalapú megoldás, azonban léteznek olyan termékek és szolgáltatások, melyek egyik csoportba sem sorolhatók be egyértelmúen, mivel a fizetési folyamat után azonnal igénybe lehet óket venni (pl. e-könyvek, szoftverek, online pénzügyi szolgáltatások). Ezt a hiányosságot megragadva vezette be Francis és White $(2003,2004)$ az elektronikus és az offline teljesítés kategóriáját. Elektronikus teljesítés esetében a vásárlónak a tranzakció után az elektroni- kus környezetben kell „maradnia”, hogy letöltse vagy „elfogyassza” a vásárolt jószágot, míg offline esetben a megrendelés után elhagyhatja a virtuális világot. Ezek alapján egy $2 * 2$-es mátrix alakul ki négy kategóriával (Francis - White, 2003, 2004): (1) offline termékek, (2) offline szolgáltatások, (3) elektronikus termékek és (4) elektronikus szolgáltatások (1.ábra).

\section{Az e-kereskedelem kategóriái a teljesítés módja és a termék jellege szerint}

\begin{tabular}{|c|c|c|c|}
\hline & \multicolumn{2}{|c|}{ TELJESÍTÉS MÓDJA } \\
\hline & & Offline & Elektronikus \\
\hline \multirow{4}{*}{ 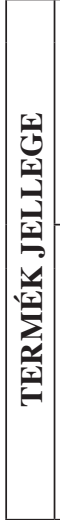 } & & Offline termékek & E-termékek \\
\hline & & $\begin{array}{l}\text { A vásárló online rendel, } \\
\text { azonban offline kapja meg } \\
\text { a terméket } \\
\text { pl. könyv, mobiltelefon, } \\
\text { bútor stb. }\end{array}$ & $\begin{array}{l}\text { A vásárló fizetés után egy- } \\
\text { ből letölti a terméket, és } \\
\text { előkészíti a fogyasztásra } \\
\text { pl. szoftverek, MP3, e-új- } \\
\text { ságok stb. }\end{array}$ \\
\hline & & Offline szolgáltatások & E-szolgáltatások \\
\hline & 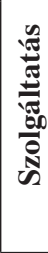 & $\begin{array}{l}\text { A rendelés online történik, } \\
\text { de az egyén offline kell, } \\
\text { hogy eljusson a szolgálta- } \\
\text { tóhoz } \\
\text { pl. utazás, szállás, belépő- } \\
\text { jegyek, masszázs stb. }\end{array}$ & $\begin{array}{l}\text { Egy felhasználói fiókot } \\
\text { hoz létre az egyén, mely } \\
\text { szuikséges ahhoz, hogy } \\
\text { elfogyaszthassa a fó szol- } \\
\text { gáltatást } \\
\text { pl. e-bankolás, chatszobák, } \\
\text { részvénykereskedés stb. }\end{array}$ \\
\hline
\end{tabular}

Forrás: Francis - White (2003, 2004)

Az offline termék és szolgáltatások esetében a vásárló online rendel, azonban offline kapja meg a terméket (pl. könyv, mobiltelefon, bútor), illetve veszi igénybe a szolgáltatást (pl. utazás, szállás, belépőjegyek, maszszázs). Ezen esetek többségében a késleltetett fizetés, valamint a későbbi cserefolyamat a jellemző (Francis - White, 2004). Ezzel szemben az elektronikus termékek esetében a vásárló fizetés után egyből letölti a terméket, és előkészíti a fogyasztásra (pl. szoftverek, MP3, elektronikus újságok), míg az elektronikus szolgáltatás vásárlásakor egy felhasználói fiókot hoz létre az egyén, mely szükséges ahhoz, hogy elfogyaszthassa a fő szolgáltatást (pl. e-bankolás, chatszobák, részvénykereskedés) (Francis - White, 2002, 2003, 2004; Francis, 2007). Ebbe a kategóriába tartozik az online pénzügyi szolgáltatások igénybevétele is.

\section{Az érték és a minőség kapcsolata}

Az érték és a minőség mérése kapcsán sokszor hasonló vagy ugyanolyan megoldásokkal találkozhatunk (Gyulavári, 2005), mégis érdemes a két fogalmat külön értelmezni. Az érték a marketing egy jelentős eleme a 
minőséghez, az elégedettséghez, illetve a lojalitáshoz fúződő viszonya miatt (Cronin et al., 2000; McDougall - Levesque, 2000), mely magába foglalja, hogy mit kapott a fogyasztó (fogyasztói output) azért, amit adott (fogyasztói input) (Oliver - DeSarbo, 1988). Az értéket tehát ,a minőség, a kiszolgálás és az ár kombinációjának tekinthetjük, melyet a »vevóérték hármasának « neveznek" (Kotler - Keller, 2008, 62. old.).

Amennyiben a minőség és a kiszolgálás javul, az érték is nő, míg az ár növekedésével csökken. A marketing szempontjából a fogyasztói észlelt érték bír kiemelt szereppel (Rekettye, 1997).

$\mathrm{Az}$ érték vásárlásonként változhat, ezért fontos megérteni a vevői motivációkat. A vásárlás során két jelentôs célt különböztethetünk meg: a haszonelvút és az élvezetit, vagy más néven hedonistát (Hirschman Holbrook, 1982). Az elóbbi célvezérelt, racionális, ahol a vásárlás egy feladat vagy kötelezettség (Babin et al., 1994). Ilyenkor az érték a tranzakció idôben és hatékonyan történő teljesítéséből fakad (Babin et al., 1994), vagyis az értékek és áldozatok summázott értékét jelöli (Fu-Ling - Chuan, 2012). Ezzel szemben a hedonista érték esetében a vásárlás során az élmény, a jókedv és az élvezet kerül középpontba (Babin et al., 1994; Childers et al., 2001). A vásárlási folyamat azonban sokszor mindkét jegyet is tartalmazhatja, például amikor egy kívánt terméket akciós áron tudunk megvenni (Babin et al., 1994).

$\mathrm{Az}$ internetes vásárlást és a szolgáltatások online igénybevételét a hedonista és a haszonelvú értékek szempontjából általában homogén tevékenységként jellemezték. Úgy gondolták, hogy e tevékenységek haszonelvú, céltudatos, célorientált folyamatok, melynek célja a hatékonyság növelése, vagyis minél gyorsabban és minél kényelmesebben tudják a legtöbb információt, és így a legjobb ajánlatot elérni az egyének (Childers et al., 2001; Szymanski - Hise, 2000). Az online fogyasztók már sokkal tudatosabbak, ami az információkeresésben is tetten érhető, és tudatosan igyekeznek a legértékesebb ajánlatot megtalálni (Fu-Ling - Chuan, 2012). Az online vásárlás haszonelvú értékei közé tartozik tehát az időspórolás, a pénzspórolás, a kényelmesség és a választék mélysége.

Ezzel szemben napjainkban a hedonista értékek, vagyis a szórakozás és az élmények keresése is megjelenik az online közegben, így a legújabb kutatások szerint az online vásárláshoz köthetó tevékenységek is vegyes értékszemléletúek (Overby - Lee, 2006). Francis és White (2003) kutatása is bizonyítja, hogy a haszonelvú megközelítés mellett a hedonista értékek is megjelennek az elektronikus vásárlás során, mint például a keresési, „vadászási” folyamat, az egyedi, különleges termékek felkutatása, az online aukciókon való részvétel, illetve a chatszobákban, fórumokon a többi fogyasztóval való kommunikáció esélye. Ugyancsak a hedonista értékek közé sorolható még a vizuális élmény, az interaktivitás, a színek, a hangok (Childers et al., 2001).

\section{Az elektronikus szolgáltatás minősége}

$\mathrm{Az}$ online tranzakciókhoz tartozó szolgáltatásminőség-koncepció újfajta megközelítést igényel, mivel az offline folyamatokkal szemben számos sajátosságot tartalmaz. Az internet terjedésének korai szakaszában a cégek azt hitték, hogy az alacsony ár, illetve a webes jelenlét elegendő a sikerhez (Petre et al., 2003), azonban az online fogyasztói és vállalati tapasztalatok gyarapodásával, a verseny élesedésével és az internetes vásárlás rutinná válásával (Yoo - Donthu, 2001) rá kellett döbbenniük, hogy ez nem elég. Amennyiben a kívánt információk nem elérhetők a honlapon, a vállalat nem válaszolja meg időben az e-maileket, vagy esetleg nem tökéletes a mobiltelefonra optimalizálás a fogyasztók sokkal alacsonyabban értékelik az adott cég által nyújtott minőséget, és a jövőben a versenytársakat fogják választani.

A tranzakció tényleges környezetével a fogyasztó az információgyújjtési, vásárlási, valamint a vásárlás utáni interakciók esetében közvetlenül találkozik, azonban a teljes élményt az előtte, valamint az utána lévő szakaszok is befolyásolják. Petre és társainak modellje (2005) alapján a teljes online tranzakciós folyamatot a vásárló ennek az összképnek a függ vényében értékeli.

A minőség értékelése a szolgáltatások online vásárlása és igénybevétele esetében tehát nemcsak a tényleges tranzakciókra korlátozódik, hanem az elektronikus szolgáltatások teljes skáláját magában foglalja (Zeithaml et al., 2002; Wolfinbarger - Gilly, 2003; Petre et al., 2005; Bauer et al., 2006). Az elektronikus szolgáltatások minden olyan interaktív szolgáltatást tartalmaznak, amelyet az interneten közvetítenek a telekommunikáció, valamint az információs és a többcsatornás technológiák előnyeit használva (Sousa - Voss, 2006; Fassnacht - Koese, 2006). Ez azt jelenti, hogy a minőség értékelésekor a tranzakció közbeni események mellett figyelembe kell venni az ún. pre- és posztinterakciós szolgáltatási aspektusokat is, mint például az információgyújités folyamatát, a tranzakció teljesülését, az ügyfélszolgálatot vagy az esetleges visszatérítéseket, a problémák kezelését.

Ezek alapján a továbbiakban az online tranzakciókhoz kapcsolódó szolgáltatásminőséget a szakirodalomban is használatos eelektronikusszolgáltatás-minőség kifejezéssel illetjük, mely magában foglalja, hogy egy honlap milyen szinten képes a hatékony és eredményes nézelődést, vásárlást, illetve kiszállítást támogatni (Zeithaml et al., 2002), függetlenül attól, hogy terméket és/ vagy szolgáltatást értékesít-e az adott shop. 
Parasuraman és társai (2000) szerint az elektronikus szolgáltatás minősége esetében egy invertált U-görbe pályájú kapcsolat figyelhető meg: míg offline esetben általában a legtöbbet akarják a fogyasztók elérni, addig online esetben van egy telítődési pont. Az általuk felhozott példa szerint a vásárlók szeretnek visszajelzést kapni arról, hogy a rendelésüket elfogadták-e, valamint még az utánkövető e-mailek is rendben vannak, de van egy pont, amikor már elég a levelekből, és a további információáradat a minőség rontásához, ezen keresztül pedig az elégedettségük csökkenéséhez vezet.

\section{Az elégedettség és annak következményei az e-kereskedelem esetében}

Az elégedettség egy érzelmi állapot, mely a negatív, illetve a pozitív elvárások és élmények tükrében alakul ki (Oliver, 1980). Hasonló Parasuraman és társainak definíciója is (1994), mely szerint az elégedettség megmutatja, hogy az egyéni elvárásokhoz képest a teljesítmény hogyan alakult (Chen - Cheng, 2012). Rust és Oliver (1994, in: Chang et al., 2009) megfogalmazásában az elégedettség annak a foka, hogy a fogyasztó mennyire hisz abban, hogy valaminek a birtoklása vagy használata pozitív érzéseket kelthet benne. Oliver (1999) szerint mivel a fogyasztás valamilyen célt, vágyat elégít ki, ezért fontos, hogy azt kellemesnek érezzék. Az elégedettség ennek a kellemes teljesülésnek az érzete (Oliver, 1999).

Hasonlóan a korábbi megfogalmazásokhoz, az elégedettség online környezetben is a fogyasztói élmény értékelését jelenti az adott felülettel kapcsolatban, a korábbi tapasztalatokat figyelembe véve (Anderson Srinivasan, 2003). Az e-kereskedelem esetében, amikor csak egyszer használja valaki az adott web-shopot, pl. foglal egy szobát, akkor tranzakciós elégedettségről beszélünk, míg többszöri, ismételt vásárlás esetén kumuláltról.

Az információs rendszerek irodalmában az elégedettség a vélemények összessége egy rendszer attribútumairól a hatékonyságra koncentrálva, amelynek fó elemei a design és az implementációs tevékenységek. Az elégedettséget tehát az információ tartalma, a személyre szabott szolgáltatások, a felhasználói felület, illetve a rendszerértékek dimenziói határozzák meg $(\mathrm{Lu}$ et al., 2012).

A fogyasztó elégedettsége a korábbi vásárlási tapasztalatait figyelembe véve alakul ki egy adott elektronikus kereskedelmi céggel, amely befolyásolja az újravásárlási szándékot (Hsu et al., 2012). Wolfinbarger és Gilly (2003) eredményei alapján megállapítható, hogy a fogyasztói elégedettségben a megbízhatóság dimenziója bizonyult a legfontosabbnak, és ha a minőségdimenziók közvetlen hatását vizsgáljuk az újravásárlási szándékra, akkor ez a második legfontosabb tényezó. Loiacono, Watson és Goodhue (2007) eredményei is alátámasztják az elégedettség hatását az újralátogatásra, illetve az újravásárlásra. Ha, Muthaly és Akamavi (2010) kutatása alapján is elfogadható az a feltevés, hogy az elégedettség közvetlenül befolyásolja az online újravásárlási szándékot. Kim (2012) szerint az elégedettség vizsgálata online környezetben az újravásárlással kapcsolatban azért is fontos, mert sokszor a fizetés a szállítás előtt történik, ezért az eladónak bizalmat kell biztosítania. Amennyiben a fogyasztó elégedetett, kölcsönös megértés alakul ki, és sokkal valószínúbb, hogy a kapcsolatuk folytatódik. Amennyiben az elégedettség a teljesítménnyel kapcsolatban nő, akkor a tranzakciók megismétlésének szándéka - az újravásárlási szándék is nő (Kim, 2012).

Az elégedettség befolyásolja a szájreklámot is (Moon et al., 2011), mely a vásárlási döntési szituációban egy jelentős, külső, megbízható információforrás, amit olyan egyén vagy vállalkozás indíthat, akinek tapasztalata van az adott termékkel, szolgáltatással kapcsolatban, és ennek köszönhetően megfelelő információt juttat el a befogadó számára (Eszes, 2011). A szájreklámnak szolgáltatások esetében különösen jelentôs a hatása (Kenesei - Kolos, 2007).

Napjainkban a fogyasztók számára elérhetó, internetezésre alkalmas eszközök és megoldások lehetővé tették az online szájreklám kialakulását, amely elsősorban abban különbözik a hagyományos formától, hogy mivel elektronikus felületen zajlik, általában nincs közvetlen face-to-face kommunikáció, a vélemények, ajánlások alapvetôen kéretlenek, és csak akkor értékelik ôket, ha a leendó befogadók éppen rájuk találnak (Park - Kim, 2008). Az e-WOM esetében a vélemények a korábban megszokottnál nagyobb mértékben és sebességgel terjedhetnek. A hagyományos szájreklám esetében az információt privát beszélgetések során adják át, míg online esetben olyan egyénekhez, csoportokhoz is eljuthat, akik nincsenek jelen az adott pillanatban (Karakaya - Barnes, 2010), vagy nem ismerik, illetve ismerhetik egymást. Míg offline esetben egyidejú véleménymegosztás történik egyének vagy kisebb csoportok között (Steffes - Burgee, 2009), addig online esetben aszinkron (Hung - Li, 2007), több utas formában kerül rá sor, amelynek révén tartósabbnak és elérhetőbbnek is tekinthetô. Ezáltal az e-WOM mérhetőbbé, elemezhetôbbé is válik (Park - Kim, 2008), hiszen általában elöre meg nem határozott ideig tárolható (Hennig-Thurau et al., 2004).

\section{A kutatási design}

Primer kutatásunk fókuszában a pénzügyi szolgáltatások online vásárlásának minőségészlelése, az ezzel 
kapcsolatos elégedettség, továbbajánlási és újravásárlási hajlandóság mérése áll. A kutatási kérdések megválaszolására egy online panelt használva kérdőíves adatfelvételt folytattunk, melynek során 1000 olyan egyént kérdeztünk meg, akik az elmúlt három hónapban valamilyen terméket vagy szolgáltatást vásároltak online. A mintavétel során egy kvótát határoztunk meg, melynek értelmében a minta egyik felét az offline terméket vagy szolgáltatást vásárlók, míg a másikat az elektronikus terméket vagy szolgáltatást vásárlók tették ki. Jelen tanulmány a kutatásban részt vevő azon egyénekre koncentrál, akik valamilyen pénzügyi szolgáltatást vásároltak: ôk a teljes minta 16,8\%-át jelentik (168 fó). E megkérdezettek többsége (99 fó, 53,6\%) biztosítást kötött kizárólag online felületet felhasználva, 38,7\%-uk (65 fő) e-bankolási tevékenységet, míg a maradék 13 fő online tőzsdei tevékenységet folytatott. készségét. A többi esetben jelentôs eltérések figyelhetôk meg. A honlapminőség az offline termékek és szolgáltatások esetében hasonló elemeket tartalmaz, úgymint a design, a tartalom, a termékek száma, míg az elektronikus termékeknél inkább a termékjellemzóket (méret, rendszerfeltételek, kompatibilitás), az elektronikus szolgáltatásoknál pedig a felhasználói fiók létrehozásának egyszerúségét, gyorsaságát foglalja össze ez a dimenzió. A fizetésre és kézhezvételre vonatkozó kategóriába tartozik az offline termék esetében a rendelés megvalósítása, a megfelelő termék jó időben történő szállítása, míg az elektronikus terméknél a teljesítés minősége, a letöltési instrukciók egyértelmúsége és a gyorsaság. Offline szolgáltatásoknál a foglalás egyszerúsége, megbízhatósága, az egyértelmú, gyors visszaigazolás, az elektronikus szolgáltatásoknál pedig az egyszerú, megbízható bejelentkezés, az egyszerú használat és a szolgáltatás leírása tartozik a kategóriába (1. táblázat).

\section{A kutatásban felhasznált RECIPE skála dimenziói}

\begin{tabular}{lcc}
\hline \multicolumn{1}{c}{ Dimenzió általános elnevezése } & Offline termék & Offline szolgáltatás \\
\hline 1. Az online felület minősége & Honlapminőség & Honlapminőség \\
2. Vásárlás lebonyolításának minősége & Csere: fizetés és kézhezvétel & Foglalás/vásárlás \\
3. Ügyfélszolgálat & Ügyfélszolgálat & Ügyfélszolgálat \\
4. Biztonság & Biztonság & Biztonság \\
\hline \multicolumn{1}{c}{ Dimenzió általános elnevezése } & Elektronikus termék & Elektronikus szolgáltatás \\
\hline 1. Az online felület minősége & Termékrészletek & Felhasználói fióklétrehozás \\
2. Vásárlás lebonyolításának minősége & Csere: fizetés és kézhezvétel & Rendszer kezelése \\
3. Ügyfélszolgálat & Ügyfélszolgálat & Ügyfélszolgálat \\
4. Biztonság & Biztonság & Biztonság \\
\hline
\end{tabular}

A kutatás során a megkérdezettek utolsó vásárlásához köthető minőségészlelését, elégedettségét, hagyományos és elektronikus továbbajánlási és újravásárlási hajlandóságát mértük. A pénzügyi szolgáltatások online vásárláshoz köthető minőségészlelést a Francis (2009) által megalkotott RECIPE (Review and Evaluate the Customer's Internet Purchase Experience) skálával mértük, mely négy dimenziót tartalmaz, melyek összefoglaló elnevezései: (1) online felület minősége, (2) vásárlás lebonyolításának minősége, (3) ügyfélszolgálat, illetve (4) biztonság (Francis, 2009).

Az e-kereskedelmi csoportok dimenzióinak tényleges elemei az egyes jószágok és igénybevételi módok esetében különböznek, emiatt a skála mérési tételei az egyes kategóriák esetében eltérnek ${ }^{2}$. Azonos módon mértük a biztonságot, vagyis a kártyaadatok és a személyes információk biztonságát, valamint az ügyfélszolgálat dimenzióját, úgymint a cég elérhetőségét, gyorsaságát, segítő-
A Francis (2009) által megalkotott skála alapos áttanulmányozása alapján megállapítható, hogy a tanulmány középpontjában álló elektronikus szolgáltatások esetében a felhasználói fiók létrehozása mellett a rendszerkezelés dimenziója is a konkrét online felülethez kapcsolódó minőségi szempontokat tartalmazzák, így ezekeket érdemes közösen, egy magasabb rendú faktorban (second-order construct) értelmezni. Ennek megfelelóen ezt a továbbiakban a konkrét honlaphoz kapcsolódó minőség dimenziónak fogjuk hívni.

A pénzügyi szolgáltatások online vásárlásához köthető minőségészlelés, elégedettség és annak következményeit először leíró jellemzőkkel mutatjuk be részletesen, majd a mélyebb megértése céljából a strukturális modellezés módszertanát felhasználva az oksági összefüggéseket is vizsgáljuk. A korábban bemutatott szakirodalomi összefüggések alapján az alábbi hipotéziseket állítjuk fel: 
H1: A konkrét honlaphoz kapcsolódó minőség dimenziója pozitív hatással bír az elégedettség alakulására.

H2: Az ügyfélszolgálat észlelt minősége és az adott weboldallal kapcsolatos elégedettség között pozitív kapcsolat van.

H3: Az észlelt biztonság dimenziója pozitív hatással bír az elégedettség alakulására.

H4: Az elégedettség pozitív hatással bír a hagyományos továbbajánlási szándékra.

H5: Az elégedettség pozitív hatással bír az elektronikus továbbajánlási szándékra.

H6: Az elégedettség pozitív hatással bír az újravásárlási szándékra.

A marketing területén két eltérő módszertan használata jellemző a látens változókkal is rendelkező oksági összefüggések vizsgálatára. A kovarianciaalapú modellezés (CB-SEM) a változók együttmozgásából indul ki, míg a varianciaalapú modellezés (PLS-SEM) a változók varianciájából. A CB-SEM esetében mindössze a közös varianciát elemezzük - a kovariancia is ezen alapszik -, míg a PLS-SEM esetében a variancia mindhárom fajtáját, vagyis a közös varianciát, az egyéni/specifikus varianciát, valamint a hibatagokat is figyelembe veszik (Kemény, 2015). A két módszertan legjelentősebb különbségeit a 2. táblázat foglalja össze.

\section{2. táblázat}

\section{A PLS és a CB-SEM jellemzői}

\begin{tabular}{|c|c|c|}
\hline Elvárás & PLS & CB-SEM \\
\hline Célja & Előrejelzés-orientált & Paraméter-orientált \\
\hline Eljárás & Varianciaalapú & Kovarianciaalapú \\
\hline Előfeltétel & $\begin{array}{l}\text { A mutatók specifiká- } \\
\text { lása (nem paramet- } \\
\text { rikus) }\end{array}$ & $\begin{array}{l}\text { Normális eloszlás és } \\
\text { független megfigyelés } \\
\text { (parametrikus) }\end{array}$ \\
\hline $\begin{array}{l}\text { Paraméter- } \\
\text { becslés }\end{array}$ & $\begin{array}{l}\text { Minél több változó } \\
\text { van, annál több para- } \\
\text { méter kell }\end{array}$ & Konzisztens \\
\hline $\begin{array}{l}\text { Látens válto- } \\
\text { zók értéke }\end{array}$ & Explicit becsült & Határozatlan \\
\hline $\begin{array}{l}\text { Modell- } \\
\text { komplexitás }\end{array}$ & $\begin{array}{l}\text { Nagy (pl. } 100 \text { elmé- } \\
\text { leti fogalomhoz } 1000 \\
\text { indikátor) }\end{array}$ & $\begin{array}{l}\text { Kicsi (kevesebb, mint } \\
100 \text { indikátor) }\end{array}$ \\
\hline Mintaméret & $\begin{array}{l}\text { Minimum elemszám } \\
\text { 30-100 között van. A } \\
\text { mutatóktól függ. }\end{array}$ & $\begin{array}{l}\text { Minimum elemszám } \\
\text { 200-800 között. }\end{array}$ \\
\hline
\end{tabular}

Forrás: Chin-Newsted (1999 in Kemény, 2015)

Jelen tanulmány során a varianciaalapú modellezést használjuk, ugyanis ennek a módszernek nem feltétele a vizsgálatba bevont változók normális eloszlása, és a Kolmogorov-Smirnov próba alapján a normál eloszlás- tól különböző eloszlással találkozunk a kutatás során. Ugyancsak a PLS-SEM módszertan mellett szól a kis mintaelemszám is.

A modellben találkozhatunk egy másodlagos faktorral, melyet a felhasználói fiók létrehozásának minősége és a rendszerkezelés felhasználhatósága dimenziók közösen alkotnak. A másodlagos fogalmak kezelésére az irodalom három megoldást kínál: az ismételt indikátor megoldást (repeated indicatior approach), a két lépcső (two stages approach) megoldást, illetve a kevésbé elterjedt hibrid megoldást (hibrid approach) (van Riel et al., 2017). Jelen esetben a látens, másodlagos dimenziót megalkotó komponensek reflektív módon alakulnak, míg ezek a látensek által létrehozott másodlagos változó már formatív módon jön létre, hiszen a két dimenzió okozataként keletkezik az új változó. Kutatásunk során a kétlépcsős megoldást alkalmazzuk, ezzel is kiküszöbölve az ismételt indikátor folyamatnál megjelenő mesterségesen korreláló hibatagok problémáját (Becker et al., 2012). A folyamat lényege, hogy a másodlagos, magasabb rendú változó értékét az elsődleges változó PLS-SEM által kalkulált látens változói értékeivel, mint manifeszt változókkal kalkuláljuk. Tehát első lépésben ezeket a látens értékeket kell kiszámolni, majd ezen értékeket, mint indikátorokat behelyettesítve számolható ki a végleges modell és az útegyütthatók. A módszer alkalmazásának előnye, hogy elkerüli az ismételt indikátorok közötti mesterséges multikollinearitást (Arnett et al., 2003).

Primer kutatásunk értékelését a válaszadók szegmentálásával zárjuk, mely a vállalatok számára egyfajta stratégiai útmutatást jelenthet. Elemzésünkhöz az SPSS 22.0 és az Adanco programokat használtuk.

\section{Eredmények és következtetések}

A mintában résztvevők 60,7\%-a (102 fó) nő, az átlagos életkor 48,75 év (szórás=12,20 év), és 72,6\%-uk valamilyen nagyobb településen el. 67,3\%-uk legalább felsôfokú végzettséggel rendelkezik, és $73,2 \%$-uk olyan jövedelemmel bír, mely lehetővé teszi az alapvetô dolgok megvásárlásán túli fogyasztást. A részletes demográfiai adatokat a 3. táblázat foglalja össze.

A pénzügyi szolgáltatást online vásárló 168 fő többsége aktív internetes vásárlónak számít: $66,1 \%$-uk legalább havonta szokott valamilyen terméket vagy szolgáltatást online vásárolni. Az elemzés középpontjában álló utolsó online tranzakciójuk során a válaszadók 51,8\%-a mindössze 6.000 Ft-ot költött, míg 10,1\%-uk legalább 50.000 Ft-ot. A 13 online tózsdézőből 8 fó ebbe az utóbbi kategóriába tartozik. Az extrémen kiugró költéseket, vagyis a $65.000 \mathrm{Ft}$-nál magasabb költségeket kizárva (16 fó), is megállapítható, hogy a vizsgált három pénzügyi szolgáltatás online vásárlása során szig- 


\section{A minta jellemzői}

\section{3. táblázat}

\begin{tabular}{|c|c|c|c|}
\hline \multicolumn{2}{|c|}{ Válaszadó neme } & \multicolumn{2}{|l|}{ Háztartás jövedelme } \\
\hline férfi & $39,29 \%$ & $\begin{array}{l}\text { Arra sem elég a havi } \\
\text { jövedelmem/ünk, hogy az } \\
\text { alapvetó dolgok }\end{array}$ & $5,36 \%$ \\
\hline nó & $60,71 \%$ & $\begin{array}{l}\text { Az alapvetố dolgokat meg } \\
\text { tudom/juk vásárolni, de } \\
\text { másra nincs }\end{array}$ & $21,43 \%$ \\
\hline \multicolumn{2}{|l|}{ Életkor } & $\begin{array}{l}\text { Meg tudom/juk vásárolni az } \\
\text { alapvető dolgokat és egy-két }\end{array}$ & $52,98 \%$ \\
\hline Átlag & 48,7 év & $\begin{array}{l}\text { Könnyedén meg tudom/juk } \\
\text { vásárolni, amire szükségem/ } \\
\text { ünk van, }\end{array}$ & $20,24 \%$ \\
\hline Szórás & 13,2 év & $\begin{array}{l}\text { Milyen gyakran szokott onli } \\
\text { vásárolni? }\end{array}$ & \\
\hline \multicolumn{2}{|c|}{$\begin{array}{l}\text { Legmagasabb iskolai } \\
\text { végzettsége }\end{array}$} & Hetente többször & $7,74 \%$ \\
\hline $\begin{array}{l}\text { szakiskola, } \\
\text { szakmunkás- } \\
\text { képző }\end{array}$ & $5,36 \%$ & Hetente egyszer & $7,14 \%$ \\
\hline középiskola & $27,38 \%$ & Kéthetente & $13,69 \%$ \\
\hline föiskola & $29,17 \%$ & Havonta & $37,50 \%$ \\
\hline egyetem & $36,31 \%$ & Kéthavonta & $13,69 \%$ \\
\hline egyéb & $1,79 \%$ & Négyhavonta & $8,33 \%$ \\
\hline \multicolumn{2}{|l|}{ Lakhely } & Négyhavonta & $11,90 \%$ \\
\hline fơváros & $40,48 \%$ & & \\
\hline megyeszékhely & $23,21 \%$ & & \\
\hline $\begin{array}{l}\text { egyéb nagy- } \\
\text { város }\end{array}$ & $8,93 \%$ & & \\
\hline falu & $27,38 \%$ & & \\
\hline
\end{tabular}

Forrás: primer kutatás alapján

nifikáns különbség ${ }^{3}$ figyelhetô meg az átlagos költésben $(\mathrm{F}=6,804$; szig=0,001). A legmagasabb átlagos költéssel az online tőzsdézők rendelkeznek (átlag=17.200 Ft), míg legalacsonyabb költés az e-bankolók esetében figyelhetó meg (átlag=5.583,5 Ft) $(4$. táblázat)

\section{Az igénybevett pénzügyi szolgáltatás jellemzői}

4. táblázat

\section{Milyen szolgáltatás vásárolt/vett igénybe?}

\begin{tabular}{lc}
\hline Online tőzsde, részvényvásárlás & 13 fő $(7,74 \%)$ \\
E-bankolás & 65 fó $(38,69 \%)$ \\
$\begin{array}{l}\text { Biztosításkötés kizárólag } \\
\text { az online felületet felhasználva }\end{array}$ & 90 fó $(53,57 \%)$ \\
\hline
\end{tabular}

Milyen értékben vásárolt?

\begin{tabular}{lccc}
\hline $\begin{array}{l}\text { Online tózsde, } \\
\text { részvényvásárlás }\end{array}$ & $17200,00 \mathrm{HUF}$ & $19047,31 \mathrm{HUF}$ & \\
E-bankolás & $5583,50 \mathrm{HUF}$ & $12097,03 \mathrm{HUF}$ & $\mathrm{F}=6,804$ \\
Biztosításkötés & $12328,80 \mathrm{HUF}$ & $11411,11 \mathrm{HUF}$ & szig=0,001 \\
Teljes & $9769,71 \mathrm{HUF}$ & $12479,44 \mathrm{HUF}$ & \\
\hline \multicolumn{4}{c}{ Forrás: primer kutatás alapján }
\end{tabular}

A pénzügyi szolgáltatások online vásárlásához köthető minőségészlelést a Francis (2009) által meghatározott és a tanulmány korábbi részében bemutatott 4 dimenzió mentén mértük, vagyis a felhasználói fiók létrehozásához kapcsolódó minőségelemek, a rendszer/ fiók kezelése, az ügyfélszolgálat minősége és a biztonság dimenziók alapján. Az észlelt minőség mérése során az állításokkal való egyetértést 1-től 7-ig skálán mértük, ahol az 1-es jelentette, hogy az egyén egyáltalán nem ért egyet az adott kijelentéssel, míg a 7-es, hogy teljes mértékben egyetért.

5. táblázat

\section{A vásárlás értékelése}

\begin{tabular}{lcccc}
\hline & $N$ & Átlag & Szórás \\
\hline 1. A konkrét honlaphoz kapcsolódó minóség ÁTLAG & $\mathbf{1 6 8}$ & $\mathbf{6 , 2 8}$ & $\mathbf{1 , 0 4 4}$ \\
\hline 1a. Rendszerkezelés ÁTLAG & $\mathbf{1 6 8}$ & $\mathbf{6 , 3 1}$ & $\mathbf{0 , 9 9 7}$ \\
\hline A felhasználói fiókomat/tagságomat visszaigazolták. & 168 & 6,26 & 1,44 \\
A felhasználói fiókomba való bejelentkezés egyszerú. & 168 & 6,33 & 1,24 \\
Az online szolgáltatásokhoz való hozzáférés megbízható. & 168 & 6,33 & 1,07 \\
Az online szolgáltatások azonnal elérhetőek voltak. & 168 & 6,37 & 1,14 \\
A fiók/tagság használata egyszerú. & 168 & 6,28 & 1,14
\end{tabular}

A nyúitott online szolgáltatás olyan volt mint amilyennek leírták.

\begin{tabular}{lllll} 
1b. Fiók létrehozás ÁTLAG & 168 & 6,25 & 1,151 \\
\hline
\end{tabular}

A felhasználói fiók létrehozásáról szóló útmutató egyértelmú volt. $\quad 168 \quad 6,24 \quad 1,19$

A felhasználói fiók létrehozása egyszerú volt. $\quad 168 \quad 6,17 \quad 1,23$

A felhasználói fiók létrehozása már elsőre sikerült. $\quad \begin{array}{llll}168 & 6,38 & 1,24\end{array}$

A felhasználói fiókom/tagságom azonnal létrejött. $\quad \begin{array}{llll}168 & 6,18 & 1,56\end{array}$

\begin{tabular}{llll} 
2. Ügyfélszolgálat ÁTLAG & $\mathbf{8 8}$ & $\mathbf{5 , 8}$ & $\mathbf{1 , 2 2 4}$ \\
\hline
\end{tabular}

\begin{tabular}{llll}
\hline Az ügyfélszolgálat online is elérhetó. & 168 & 5,94 & 1,67
\end{tabular}

$\begin{array}{llll}\text { Az ügyfélszolgáltat elérése egyszerú volt. } & 125 & 6,01 & 1,43\end{array}$

$\begin{array}{lllll}\text { A vállalat gyorsan válaszolt az e-mailemre. } & 121 & 6,08 & 1,31\end{array}$

A vállalattal folytatott kommunikáció személyes hangvételú volt. $\quad 117 \quad 5,58 \quad 1,62$

A kérdése(i)mre adott válaszok segítettek/hasznosak voltak. $\quad \begin{array}{llll}106 & 5,89 & 1,3\end{array}$

A vállalat szívesen segített a felmerülő problémák kezelé- $\quad \begin{array}{lllll}104 & 6,06 & 1,25\end{array}$

sében.

3. Biztonság ÁTLAG $\quad 156 \quad 6,29 \quad 0,975$

\begin{tabular}{lllll}
\hline A biztonsághoz kapcsolódó információk egyértelmúen & 142 & 6,18 & 1,11
\end{tabular}

voltak elmagyarázva.

$\begin{array}{lllll}\text { A bankkártyám/hitelkártyám biztonsága garantált volt. } \quad 129 & 6,25 & 1,14\end{array}$

A személyes adatok felhasználását részletesen leírták. $\quad \begin{array}{llll}145 & 6,32 & 1,04\end{array}$

\begin{tabular}{llll} 
A személyes adataimat bizalmasan kezelték. & 131 & 6,29 & 1,17 \\
\hline
\end{tabular}

Észlelt minőség ÁTLAG (e-szolg) $\quad 168 \quad 6,22 \quad 0,969$

\begin{tabular}{llll}
\hline 4. Elégedettség (SAT) ÁTLAG & 168 & $\mathbf{6 , 3 8}$ & $\mathbf{0 , 9 3 6}$
\end{tabular}

Jó döntés volt ezen az oldalon vásárolni. $168 \begin{array}{llll}6,3 & 1,07\end{array}$

Ha újra vásárolnék ezen a helyen, valószínúleg ugyanúgy $\quad \begin{array}{llll}168 & 6,41 & 0,95\end{array}$

értékelném a honlapot/céget.

Elégedett vagyok a döntésemmel, hogy ezen az oldalon $\quad 168 \quad 6,42 \quad 0,96$

\begin{tabular}{lllll} 
vásároltam. & & & & \\
\hline 5.Hagyományos továbbajánlási hajilandóság (WOM) ÁTLAG & $\mathbf{1 6 8}$ & $\mathbf{6 , 1 8}$ & $\mathbf{1 , 1 0 9}$
\end{tabular}

\begin{tabular}{lllll}
\hline Pozitív dolgokat mondanék másoknak erről a web-áruházról. & 168 & 6,3 & 1,04
\end{tabular}

Ajánlanám a web-áruházat azoknak, akik kíváncsiak a $\quad 168 \quad 6,11 \quad 1,26$

tanácsomra.

Bátorítanám a barátaimat és rokonaimat, hogy használják $\quad \begin{array}{llll}168 & 6,14 & 1,2\end{array}$

$\begin{array}{llll}\text { ezt a web-áruházat. } & 168 & 6,14 & 1,2\end{array}$

6. Az oldalról szívesen osztanék meg pozitív véleményt az $\quad \begin{array}{llll}168 & 5,24 & 1,974\end{array}$ interneten. (e-WOM)

$\begin{array}{lll}168 & 5,95 & 1,392\end{array}$

ról. (ÚJRAVÁSÁRLÁSI HAJLANDÓSÁG)

Forrás: primer kutatás alapján 
Az eredmények alapján megállapítható, hogy a vizsgált vásárlási szituációkhoz kapcsolódóan a legmagasabb átlagos minőségészlelés a rendszer/fiókkezelés dimenzióhoz tartozik (átlag ${ }_{1 \mathrm{a}}=6,31$ ), melyet a biztonság dimenzió követ (átlag $=6,29$ ). Az átlagos szummázott minőségészlelés is magasnak számít (átlag=6,23). Érdekes megfigyelés, hogy mind a biztonság, mind pedig az ügyfélszolgálat dimenzióhoz kapcsolódóan találkozhatunk hiányzó adatokkal, vagyis nem minden megkérdezett tudta a skálából átvett állításokat értékelni.

A minőségészleléshez hasonlóan az megkérdezettek elégedettsége is magas volt (átlag ${ }_{4}=6,38$ ), azonban az elégedettség következményeihez kapcsolódó értékelések ennél alacsonyabbak. Legkisebb hajlandóságot az e-WOM iránt mutatnak a megkérdezettek (átlag $\left.{ }_{6}=5,24\right)$, melyet az újravásárlási hajlandóság (átlag $=5,95$ ), majd közel a szummázott hagyományos továbbajánlási hajlandóság követnek (áltag $\left.{ }_{5}=6,18\right)(5$. táblázat)

A vizsgált három szegmens között a minőségészleléshez, elégedettséghez és annak következményeihez köthetôen szignifikáns különbség nem figyelhetô meg $(\mathrm{F}=1,251-0,071 ; \mathrm{szig}=0,289-0,931)$ (6. táblázat) .

Kutatásunk során a látens változók megbízhatóságát a Dijkstra-Henseler-féle rhó mutatóval, a látens változókhoz tartozó hasonlósági érvényességet az átlagos magyarázott varianciaértékkel (AVE), míg a különbö- sággal rendelkezik. Egyetlen egy esetben, az elégedettség és hagyományos továbbajánlási hajlandóság között nem figyelhető meg az elvárt HTMT-érték, vagyis a különbözőségi érvényesség itt nem érvényesül. Azonban ilyen szoros kapcsolatban álló ok-okozati változók esetében ez gyakran elófordul, így a további elemzések elvégezhetőek (Hair, 2013).

\section{A felhasznált változók megbízhatósága}

7. táblázat

\begin{tabular}{|c|c|c|c|c|c|c|c|c|}
\hline \multirow{2}{*}{ Változó } & \multirow{2}{*}{$\begin{array}{l}\text { Dijkstra- } \\
\text { Henseler's } \\
\text { rho (oA) }\end{array}$} & \multirow{2}{*}{ AVE } & \multicolumn{2}{|c|}{ HTMT } & \multirow[b]{2}{*}{3} & \multirow[b]{2}{*}{4} & \multirow[b]{2}{*}{5} & \multirow[b]{2}{*}{6} \\
\hline & & & 1 & 2 & & & & \\
\hline $\begin{array}{l}\text { 1. A konkrét } \\
\text { honlaphoz köthető } \\
\text { minőség }\end{array}$ & 0,890 & 0,625 & n.a. & n.a. & n.a. & n.a. & n.a. & n.a. \\
\hline $\begin{array}{l}\text { 2. Ügyfélszolgálat } \\
\text { elérhetősége }\end{array}$ & 0,883 & 0,615 & n.a. & & & & & \\
\hline 3. Biztonság & 0,912 & 0,790 & n.a. & 0,793 & & & & \\
\hline 4. Elégedettség & 0,935 & 0,884 & n.a. & 0,803 & 0,867 & & & \\
\hline 5. WOM & 0,952 & 0,904 & n.a. & 0,781 & 0,725 & 0,949 & & \\
\hline 6. E-WOM & 1,000 & 1,000 & n.a. & 0,399 & 0,333 & 0,481 & 0,644 & \\
\hline $\begin{array}{l}\text { 7. Újravásárlási } \\
\text { szándék }\end{array}$ & 1,000 & 1,000 & n.a. & 0,547 & 0,580 & 0,742 & 0,714 & 0,563 \\
\hline Elvárt érték & $\varrho A>0.8$ & $A V E>$ & & & & $T M T<0$ & 0.9 & \\
\hline SRMR & 0,061 & & & & & & & \\
\hline
\end{tabular}

Forrás: primer kutatás alapján

\section{Különbségek a különböző vásárlási szituációk esetében}

6. táblázat

\begin{tabular}{lccccccccccccc}
\hline & \multicolumn{3}{c}{$\begin{array}{c}\text { Online tózsde, } \\
\text { részvényvásárlás }\end{array}$} & \multicolumn{3}{c}{ E-bankolás } & \multicolumn{3}{c}{ Biztosításkötés } & \multicolumn{3}{c}{$\begin{array}{c}\text { Különbségek } \\
\text { értékelése }\end{array}$} \\
\hline & Átlag & Szórás & $N(f o ́)$ & Átlag & Szórás & $N(f o ́)$ & Átlag & Szórás & $\begin{array}{l}N \\
\text { (fó) }\end{array}$ & $F$-érték & Szig \\
\hline Fiók létrehozás ÁTLAG & 6,17 & 1,33 & 13 & 6,22 & 1,14 & 65 & 6,28 & 1,14 & 90 & 0,07 & 0,93 \\
Rendszerkezelés ÁTLAG & 6,35 & 0,97 & 13 & 6,24 & 1,14 & 65 & 6,36 & 0,89 & 90 & 0,28 & 0,76 \\
Ügyfélszolgálat ÁTLAG & 5,71 & 0,92 & 8 & 5,63 & 1,18 & 36 & 5,94 & 1,31 & 44 & 0,65 & 0,53 \\
Biztonság ÁTLAG & 6,51 & 0,82 & 13 & 6,17 & 1,06 & 61 & 6,35 & 0,93 & 82 & 0,97 & 0,38 \\
Észlelt minóség ÁTLAG & 6,29 & 0,93 & 13 & 6,13 & 1,09 & 65 & 6,28 & 0,89 & 90 & 0,45 & 0,64 \\
Elégedettség ÁTLAG & 6,13 & 0,81 & 13 & 6,29 & 0,98 & 65 & 6,48 & 0,92 & 90 & 1,25 & 0,29 \\
Hagyományos WOM ÁTLAG & 5,83 & 1,19 & 13 & 5,84 & 1,18 & 65 & 6,05 & 1,09 & 90 & 0,70 & 0,50 \\
E-WOM & 5,00 & 2,16 & 13 & 5,11 & 1,92 & 65 & 5,38 & 2,00 & 90 & 0,46 & 0,63 \\
Újravásárlási szándék & 6,00 & 1,68 & 13 & 6,03 & 1,26 & 65 & 5,89 & 1,45 & 90 & 0,20 & 0,82 \\
\hline
\end{tabular}

zőségi érvényességet a HTMT (heterotrait-monotrait ratio) mutatóval mértük (Henseler et al., 2016). A modell validálására a standardizált átlagos reziduális értéket használtuk (SRMR). Az eredmények alapján (7. táblázat) megállapítható, hogy mind a látens változók, mind pedig a felállított modell megfeleló megbízható-
A Francis (2009) által javasolt elektronikusszolgáltatás-minőség dimenziók közül pénzügyi szolgáltatások online vásárlása esetében mind a három szignifikáns hatású az elégedettség alakulására. Legerósebb hatással a biztonság észlelt alakulása rendelkezik $\left(\beta_{34}=0,367\right)$. A konkrét honlaphoz kapcsolódó minőség 
és az ügyfélszolgálat észlelt minősége közel azonos hatást gyakorol az elégedettségre $\left(\beta_{14}=0,286, \beta_{24}=0,280\right)$. Ezek a változók az elégedettség varianciájának $64,4 \%$ át mutatják az $\mathrm{R}^{2}$ mutató alapján. A feltételezéseknek megfelelóen az elégedettség mind a három következményre szignifikáns. Legerősebb útegyütthatóval az elégedettség és hagyományos továbbajánlási szándék esetében találkozhatunk $\left(\beta_{45}=0,843\right)$, míg a leggyengébb az elektronikus továbbajánlási szándékhoz mutat $\left(\beta_{46}=0,386\right)$. Ennek megfelelően alakulnak a magyarázott varianciahányadok is: legalacsonyabb értékel az e-WOM esetében találkozhatunk $\left(\mathrm{R}^{2}=13,5 \%\right)$, melyet az újravásárlási hajlandóság $\left(\mathrm{R}^{2}{ }_{\text {uiromás }}^{\text {ewom }}=39,4 \%\right)$, majd a hagyományos továbbajánlási szándék követnek $\left(\mathrm{R}_{\text {wom }}^{2}=71,0 \%\right)$ (8. táblázat).

\section{8. táblázat}

\section{A változók közötti közvetlen hatások alakulása}

\begin{tabular}{lllllll}
\hline \multicolumn{1}{c}{ Közvetlen hatások } & $\begin{array}{c}\text { Útegyütt- } \\
\text { ható }\end{array}$ & $\begin{array}{c}\text { Standardizált } \\
\text { bootstrap } \\
\text { értékek } \\
\text { t-érték }\end{array}$ & \multicolumn{2}{c}{$\begin{array}{c}\text { A bootsrap } \\
\text { eredték } \\
\text { határértékei }\end{array}$} \\
& $\mathbf{2 . 5 \%}$ & $\mathbf{9 7 . 5 \%}$ \\
\hline $\begin{array}{l}\text { A konkrét honlaphoz köthetón } \\
\text { minőség } \rightarrow \text { SAT }\end{array}$ & 0,241 & 3,022 & 0,003 & 0,085 & 0,396 \\
Ügyfélszolgálat $\rightarrow$ SAT & 0,280 & 2,594 & 0,010 & 0,040 & 0,468 \\
Biztonság $\rightarrow$ SAT & 0,367 & 3,666 & 0,000 & 0,162 & 0,559 \\
SAT $\rightarrow$ WOM & 0,843 & 23,456 & 0,000 & 0,764 & 0,905 \\
SAT $\rightarrow$ E-WOM & 0,628 & 10,819 & 0,000 & 0,507 & 0,738 \\
SAT $\rightarrow$ Újravásárlási szándék & 0,286 & 2,930 & 0,003 & 0,106 & 0,491 \\
\hline R2SAT & $64,40 \%$ & & & & \\
R2WOM & $71,00 \%$ & & & & \\
R2e-WOM & $13,50 \%$ & & & & \\
R2Újravás & $39,4 \%$ & & & & \\
\hline
\end{tabular}

Forrás: primer kutatás alapján

A strukturális modell esetében a direkt hatások mellett azonban érdemes a közvetett hatásokat is mérni, vagyis, hogy az e-szolgáltatásminőség dimenziói milyen hatást gyakorolnak az elégedettségen át annak következményeire. Ezen indirekt hatások mértéke nagyon hasonló a közvetlen hatások értékével, mindössze az e-WOM esetében figyelhetó meg, hogy a három minőségdimenzió értéke közel azonos hatást mutat, tehát itt az észlelt biztonság dominanciája kevésbé érvényesül (9. táblázat).

9. táblázat

\section{A változók között közvetlen hatások alakulása}

\begin{tabular}{|c|c|c|c|c|c|}
\hline \multirow[t]{2}{*}{ Közvetett hatások } & \multirow[t]{2}{*}{$\begin{array}{l}\text { Útegyütt- } \\
\text { ható }\end{array}$} & \multicolumn{2}{|c|}{$\begin{array}{c}\text { Standardizált } \\
\text { bootstrap ér- } \\
\text { tékek }\end{array}$} & \multicolumn{2}{|c|}{$\begin{array}{l}\text { A bootsrap } \\
\text { eredmények } \\
\text { határértékei }\end{array}$} \\
\hline & & t-érték & p-érték & $2.5 \%$ & $97.5 \%$ \\
\hline $\begin{array}{l}\text { A konkrét honlaphoz köthetó } \\
\text { minőség } \rightarrow \text { WOM }\end{array}$ & 0,241 & 2,826 & 0,005 & 0,087 & 0,427 \\
\hline $\begin{array}{l}\text { A konkrét honlaphoz köthető } \\
\text { minőség } \rightarrow \text { e-WOM }\end{array}$ & 0,105 & 2,690 & 0,007 & 0,033 & 0,195 \\
\hline $\begin{array}{l}\text { A konkrét honlaphoz köthető } \\
\text { minőség } \rightarrow \text { Újravásárlás }\end{array}$ & 0,179 & 2,753 & 0,006 & 0,062 & 0,322 \\
\hline Ügyfélszolgálat $\rightarrow$ WOM & 0,236 & 2,583 & 0,010 & 0,033 & 0,397 \\
\hline Ügyfélszolgálat $\rightarrow$ e-WOM & 0,103 & 2,386 & 0,017 & 0,013 & 0,185 \\
\hline Ügyfélszolgálat $\rightarrow$ Újravásárlás & 0,176 & 2,588 & 0,010 & 0,025 & 0,298 \\
\hline Biztonság $\rightarrow$ WOM & 0,310 & 3,638 & 0,000 & 0,136 & 0,469 \\
\hline Biztonság $\rightarrow$ e-WOM & 0,135 & 3,009 & 0,003 & 0,052 & 0,228 \\
\hline Biztonság $\rightarrow$ Újravásárlás & 0,231 & 3,327 & 0,001 & 0,101 & 0,372 \\
\hline
\end{tabular}

A strukturális modell eredményei azonban további elemzésekre, például szegmensek kialakítására, is felhasználhatók. Mivel jelen tanulmány fó célja az online pénzügyi szolgáltatásokhoz kapcsolódó minőségészlelés részletes megismerése, ezért a strukturális modellből az e-szolgáltatásminőség dimenziókhoz tartozó standardizált látens értékeket felhasználva végezzük el a hierarchikus klaszterelemzést (Kemény et al., 2015) a Ward-módszert felhasználva. Az elemzésünk eredményeként négy fó csoportot tudunk elkülöníteni (10. táblázat).

\section{A kialakított szegmensek jellemzése}

10. táblázat

\begin{tabular}{|c|c|c|c|c|c|c|c|c|c|}
\hline & \multirow[t]{2}{*}{ Szegmensek } & \multicolumn{2}{|c|}{$\begin{array}{c}\text { Általánosan } \\
\text { elégedettek }(N=65 \text { fó) }\end{array}$} & \multicolumn{2}{|c|}{$\begin{array}{l}\text { Kockázatcsökkentőkk } \\
(\mathrm{N}=32 \text { fö) }\end{array}$} & \multicolumn{2}{|c|}{$\begin{array}{l}\text { Online felületet } \\
\text { értékelők ( } \mathrm{N}=28 \text { fó) }\end{array}$} & \multicolumn{2}{|c|}{ 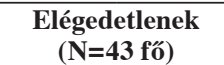 } \\
\hline & & Atlag & Szórás & Átlag & Szórás & Átlag & Szórás & Átlag & Szórás \\
\hline \multirow{3}{*}{ 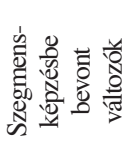 } & Konkrét honlaphoz köthető minőség & 0,646 & 0,159 & $-0,387$ & 0,334 & 0,511 & 0,239 & $-1,021$ & 1,348 \\
\hline & Ügyfélszolgálat & 0,557 & 0,532 & 0,255 & 0,354 & 0,353 & 0,409 & $-1,261$ & 1,051 \\
\hline & Biztonság & 0,745 & 0,141 & 0,148 & 0,495 & $-0,141$ & 0,332 & $-1,145$ & 1,209 \\
\hline \multirow{4}{*}{ 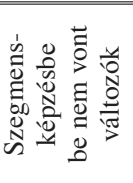 } & Elégedettség & 0,545 & 0,38 & $-0,038$ & 0,778 & 0,459 & 0,394 & $-1,094$ & 1,176 \\
\hline & WOM & 0,591 & 0,347 & $-0,045$ & 0,776 & 0,293 & 0,573 & $-1,05$ & 1,187 \\
\hline & E-WOM & 0,266 & 0,992 & $-0,314$ & 1,127 & 0,419 & 0,728 & $-0,442$ & 0,835 \\
\hline & Újravásárlási szándék & 0,388 & 0,881 & $-0,1$ & 0,92 & 0,316 & 0,766 & $-0,718$ & 0,978 \\
\hline
\end{tabular}

Forrás: primer kutatás alapján 
Legnagyobb csoportunk 65 fővel az általánosan elégedettek, akik mind a három minóségdimenzió esetében a legmagasabb értékekkel rendelkeznek (átlag $=0,646$; átlag ${ }_{2}=0,557$, átlag $\left._{3}=0,745\right)$. Az ô esetükben figyelhető meg a legmagasabb elégedettség (átlag ${ }_{4}=0,545$ ), a hagyományos továbbajánlási szándék (átlag $\left.{ }_{5}=0,591\right)$ és az újravásárlási hajlandóság is (átlag $=0,388$ ), azonban az e-továbbajánlási hajlandóság nem az ő esetükben a legmagasabb.

A második legnagyobb csoport az elégedetlenek csapata ( $\mathrm{N}=43$ fó), akik minden egyes szolgáltatásminőség-dimenziót és annak következményeit jelentôsen átlag alatt értékeltek.

A szegmensek közül a két legkisebb csoport - a kockázatcsökkentők ( $\mathrm{N}=32$ fó) és az online felületetet és támogatást értékelók csoportja ( $\mathrm{N}=28$ fó) - viselkedése a legizgalmasabb. A kockázatcsökkentôk a vizsgált honlapok esetében átlag feletti szinten értékelték az észlelt ügyfélszolgálatot (átlag $=0,225$ ) és biztonságot (átlag ${ }_{3}=0,148$ ), míg a konkrét honlaphoz kapcsolódó elemeket a második leggyengébbnek értékelték (átlag $=$ -0,387). Az ő esetükben kvázi azok a dimenziók kaptak magas értékelést, melyeknek magas minősége az emberi jelenléttel vagy a magas szintú informatikai biztonsági megoldásokkal az észlelt kockázatukat csökkenti. Ennek ellenére az elégedettségük (átlag $=-0,038$ ), hagyományos továbbajánlási (átlag $=-0,045$ ) és újravásárlási szándékuk (átlag $=-0,100$ ) átlagos szinten teljesít, és az elégedetlenekhez hasonló alacsony szintú az e-WOM hajlandóságuk (átlag $=-0,314)$.

A másik izgalmas csoport az online felületetet és támogatást értékelők, akik a konkrét honlaphoz kapcsolódó minőséget és az ügyfélszolgálatot értékelték átlag feletti szinten (átlag $=0,511$; átlag $=0,353$ ). Az elégedettség és annak következményei az ô esetükben is - hasonlóan az elégedettekhez - átlag feletti értéket mutatnak, azonban az e-továbbajánlási hajlandóság jelen csoport esetében magasabb (átlag $=0,419$ ).

A többszempontos varianciaelemzést felhasználva megállapítható, hogy az elégedettek és az online felületet és támogatást értékelôkk ügyfélszolgálat és a konkrét honlaphoz kapcsolódó minőségértékelése nem különbözik szignifikánsan ( $\operatorname{szig}_{2}=0,178 ;$ szig $_{1}=0,403$ ), míg az online felületet és támogatást értékelók csoportja és a kockázatcsökkentők között nincs szignifikáns különbség az ügyfélszolgálat és az észlelt biztonság esetében $\left(\operatorname{szig}_{2}=0,568 ; \operatorname{szig}_{3}=0,096\right)$. Ezek alapján megállapítható, hogy a szegmensképző ismérvek alapján az elégedetlenek csoportja az, amely minden egyéb szegmenstől szignifikánsan különbözik. Ezen eredményekkel ellentétben az elégedettség és azok következményei esetében igaz, hogy az elégedettek értékelése az e-WOM-ot leszámítva magasabb, mint az online felületet és támogatást értékelőké, azonban a különbségek nem tekinthetők szignifikánsnak $\left(\mathrm{szig}_{4}=0,612 ; \mathrm{szig}_{5}=0,084 ; \operatorname{szig}_{6}=0,474\right.$; $\left.\mathrm{szig}_{7}=0,725\right)$. Hasonlóan a minóségdimenziók értékeléséhez a kockázatcsökkentők és az online felületet és támogatást értékelők átlagai sem különböznek minden esetben szignifikánsan: a hagyományos továbbajánlási szándék és az újravásárlási hajlandóság esetében nincs szignifikáns különbség ( $\operatorname{szig}_{5}=0,087 ;$ szig $\left._{7}=0,074\right)$. Érdekesség azonban, hogy a minőségészlelés szempontjából különböző elégedetlenek és kockázatcsökkentők az e-továbbajánlási hajlandóság esetében nem térnek el jelentôsen $\left(\operatorname{szig}_{6}=0,562\right)$. (1. Melléklet $)$

A szegmensek esetében a demográfiai és online vásárlási profilokat megvizsgálva is felfedezhetők különbségek. A nemek aránya és az átlagos életkor a csoportokon belül a minta megoszlásához hasonlóan alakul, azonban az online felületet és támogatást értékelők esetében a középfokú végzettséggel rendelkezők aránya kimagasló (50\%, 14 fó), és ezzel összefüggésben e szegmensben a legalacsonyabb a legalacsonyabb életszínvonalon élők aránya is (10,7\%, 3 fó). Az online vásárlás szempontjából azonban legkevésbé tapasztalt csoportnak a kockázatcsökkentők számítanak: a szegmens 46,9\%-a (15 fó) ritkábban, mint havonta szokott csak online vásárolni.

\section{Konklúzió és jövơbeli kutatási irányok}

A tanulmány fó fókusza a pénzügyi szolgáltatások online vásárlásához köthető minőségészlelés folyamatának elméleteken keresztüli bemutatása, illetve egy primer online panelt használó kutatással kiegészítve megismerhettük e dimenziók alakulását egy konkrét e-vásárláshoz köthetốen. A kutatás három fó pénzügyi szolgáltatásra terjedt ki: az e-bankolás, az online biztosításkötés és az online tôzsdézés folyamatára. A leíró elemzések mellett egy modellbe rendezve a PLS-SEM módszertanát felhasználva a különböző minőségdimenziók hatását az elégedettségre és annak következményeire is megvizsgáltuk. Eredményeink alapján a felállított hipotézisek mindegyike helytálló.

$\mathrm{Az}$ útegyütthatókat megvizsgálva megállapítható, hogy a legjelentősebb hatása az elégedettség alakulása szempontjából a biztonság dimenziójának van, amely jelen szektor esetében nem tekinthető meglepőnek, hisz az e-bankolás vagy online tőzsdézés is nagyon komoly pénzügyi tranzakciókhoz és személyes információkhoz köthetô, ugyanis jelen esetben nemcsak a bankkártyákhoz köthetó információk védelme a fontos, hanem egyéb, személyes adatok, vagy akár a teljes bankolási szokásaink is magas fokú védelmet igényelnek az elégedettség növelése szempontjából.

Francis (2009), illetve Kemény (2015) korábbi munkáik során az e-szolgáltatások területét egyben vizsgálták, melyek eredményeitől jelen tanulmány, mely kizá- 
rólag a pénzügyi szolgáltatásokra koncentrál, eltérést mutat. Ez is alátámasztja azt a tényt, hogy érdemes a különböző szektorokra specializálódva, szeparált elemzéseket végezni.

A kutatásban részt vevő egyéneket részletesebb megismerés céljából a minőségdimenziók alapján a hierarchikus klaszterelemzés módszerét felhasználva homogén szegmensekbe soroltuk. A csoportjellemzés jól mutatja, hogy az elégedetlenek csoportja az, amely a minőség észlelésében teljes mértékben különbözik a többi szegmenstől, így őket érdemes mélyrehatóbban megismerni. Az eredményekből azonban az is látszik, hogy az online felületet és támogatást értékelők esetében, vagyis azok körében, akik a használt honlap és ügyfélszolgálat minőségét értékelték legjobbra, a legmagasabb a nem felsőfokú végzettséggel rendelkezők aránya. Annak ellenére, hogy az észlelt biztonságot ők átlag alatti szintre értékelték - amely a modell alapján a legfontosabb tényező az elégedettség alakulása szempontjából -, mégis az elégedettségük és annak következményeinek értékelése nem különbözik szignifikánsan az elégedettek klaszterétôl, sőt az e-továbbajánlási hajlandóság náluk a legmagasabb. Ennek részletes vizsgálata és megértése további kutatásokat igényelne, hisz lehetséges, hogy az iskolai végzettség egyfajta moderáló tényezőként jelenik meg a vizsgált kapcsolatrendszerben.

Ugyancsak érdekes eredmény, hogy a kockázatcsökkentők, vagyis azok, akik esetében az észlelt biztonság és az ügyfélszolgálat munkájának értékelése mutat átlag feletti értéket, az online vásárlásban legkevésbé tapasztalt válaszadók, hisz náluk a legmagasabb a ritkábban, mint havonta vásárlók aránya. Magyarázatként szolgálhat ez a tény is az alacsony elégedettség, illetve továbbajánlási és újravásárlási hajlandóság alakulására, azonban ennek részletes megismerése jövóbeli kutatási irányként szolgálhat.

További kutatási célként tűzhető ki az e-továbbajánlási szándék alacsony magyarázott varianciájának megértése. Habár a hagyományos WOM esetében a minóség és elégedettség megfelelő indikátorként szolgálnak a hajlandóság mérése szempontjából $\left(\mathrm{R}^{2}=71,0 \%\right)$, úgy túnik az online ajánlások esetében egyéb tényezők is jelentósek lehetnek. Nagy és társainak (2015a, 2015b), illetve Markos-Kujbus (2013) munkáját követve jelen környezetben is érdemes lenne megvizsgálni az online ajánláshoz fúződő egyéni attitúdöket és motivációkat a mélyebb megértés céljából.

\section{Menedzseri következtetések}

A tanulmányban rávilágítottunk arra, hogy az e-kereskedelem esetében a minőségészlelés egy komplex folyamat. Az elektronikus szolgáltatás minőségének részelemekre bontása azonban az e-kereskedelem különböző kategóriái esetében eltérő megközelítést igényelhet, mellyel korábbi tanulmányok is már részletesen foglalkoztak (Francis - White, 2004; Kemény, 2015). A Francis és White (2004) által megalkotott kategóriák közül az online pénzügyi szolgáltatások vásárlása az elektronikus szolgáltatások témakörébe tartozik, hisz jelen esetben olyan szolgáltatások online vásárlását elemezzük, amelyek tényleges igénybevétele is az interneten történik.

Az online banki szolgáltatások vásárlása esetén a minőség négy fő dimenzió mentén mérhetô: (1) a felhasználói fiók létrehozásának minősége, (2) a rendszerkezelés felhasználhatósága, (3) a biztonság és (4) az ügyfélszolgálat. A dimenziók közül az elsô kettő a konkrét online felülethez tartozó minőségészlelést méri, így érdemes óket egy magasabb szintú, absztrakt szinten közösen kezelni. A biztonság a tranzakció észlelt kockázatáról, vagyis a kártyaadatok és a személyes információk biztonságáról, míg az ügyfélszolgálat a kérdések és problémák menedzseléséről szól.

Az összefoglalás alapján azt is láthatjuk, hogy az elektronikusszolgáltatás-minőség dimenziói nem kifejezetten csak a technológiához kötődnek, hanem az emberi tényező, a humán központú dimenziók is megjelennek a folyamatban. A konkrét honlap minősége, a felhasználói élmény biztosítása, illetve a biztonság kialakítása egyértelmúen technológiaközpontú dimenziók, azonban az ügyfélszolgálat és teljesítés esetében a technológiai megoldások mellett az emberi tényező és viselkedés, vagyis a kínált szolgáltatás minősége is jelentôs szerepet kap. Mivel az ember által nyújtott szolgáltatások színvonala a szolgáltatások sajátosságai miatt eltéróen alakulhat, ezért ennek fejlesztésére az e-kereskedelmi vállalatoknak is nagy hangsúlyt kell fektetniük, hisz itt nem lehet minden lépést automatizálni. Napjainkban talán ez az a terület, mely a legnagyobb előnyt jelentheti a versenytársakhoz képest, hisz a panaszkezelés menedzsmentje a siker egyik kulcstényezőjeként is szolgálhat (Kenesei - Kolos, 2008).

Primer kutatásunk eredményei alapján megállapítható, hogy a vizsgált négy dimenzió közül az ügyfélszolgálattal és biztonsággal kapcsolatban a szolgáltatást igénybe vevők nem teljes köre rendelkezik tapasztalattal. A vizsgált tranzakciók esetében az ügyfélszolgálat dimenziója szerepelt a minőségészlelés szempontjából a legygyengébben, melynek megértéséhez további kutatások szükségesek, hisz ez az információ az e-kereskedelem szereplői számára is jelentős fejlesztéseket igényelhet. Érdemes a vállalatok számára a jövőben arra figyelni, hogy igaz, hogy a vásárlók többségének esetében egy probléma- és kérdésmentes folyamatról beszélhetünk, így az ügyfélszolgálattal nincsen semmilyen interakciójuk, azonban azok, akik kérdésükkel vagy gondjukkal az 
ügyfélszolgálathoz fordultak, kevésbé voltak elégedettek annak minőségével. Ebben az automatizált környezetben - főleg a kevésbé tapaszalt vásárlók esetében - kiemelkedóen fontos lehet a „személyes” (legyen az telefonos, internetes vagy valóban személyes) kapcsolatteremtés módja, így a szervezés során érdemes erre a területre is nagyobb hangsúlyt fektetni.

További jelentős eredménye a kutatásnak a biztonság kiemelkedő szerepe az elégedettség alakulása szempontjából. Habár a gyakorlati szakemberek többségének véleménye szerint a mai világban, ahol az online vásárlás akár „hétköznapi rutinként” is megjelenhet, a biztonság és adatvédelem kevésbé hangsúlyos terület, hisz erre már kiváló informatikai megoldások léteznek, mégis az eredmények azt mutatják, hogy a pénzügyi szolgáltatások online vásárlása esetében ez a változó az, melynek legerősebb a hatása az elégedettség alakulására. Véleményünk szerint, ez nem meglepő információ, hisz a pénzügyi szolgáltatások vásárlása vagy igénybevétele esetében nemcsak a bankkártyánk adatai, hanem ennél sokkal szélesebb körú információ is veszélybe kerülhet, és ezzel magyarázható az erős kapcsolat. Mégis az eredmények azt mutatják, hogy nagyon sok vásárlónak a biztonsághoz kapcsolódóan semmilyen információja nincs, így a biztonságészlelés középpontba helyezése, illetve minőségének növelése továbbra is egy kiemelt terület kell, hogy legyen a pénzügyi szektor esetében.

A vásárlók minőségészlelés szerinti szegmentálása is egyfajta stratégiai útmutatást jelenthet az érintett vállalatok számára. Érdemes a felületünket használók körében meghatározott gyakorisággal - például éves szinten - egy rövid kérdőívvel a minőségészlelés, elégedettség és annak következményeinek alakulását mérni, ezáltal a különböző csoportokhoz és egyénekhez különböző személyre szóló stratégiát tudunk kialakítani a magasabb elégedettség, és ezáltal a versenyképesség elérése céljából. Jelen esetben a négy szegmens közül a kockázatcsökkentőkkel érdemes első körben foglalkozni, hisz talán ők azok, akiket leghatékonyabban elégedettebbé lehet tenni. A kockázatcsökkentônél érdemes lenne az észlelt biztonság szintjét tovább növelni, például olyan e-DM kampányokkal, melyek erre a területre hívják fel a figyelmet. Emellett érdemes lenne azt is megismerni, hogy mi az oka a konkrét honlaphoz köthető alacsony minőségészlelésüknek, és ezekre a pontokra is hangsúlyt fektetni a jövőbeli fejlesztések során.

\section{Jegyzetek}

${ }^{1}$ Köszönetnyilvánítás: A tanulmány az OTKA-K 109792 támogatásával valósult meg. ${ }^{2}$ A részletes skálát az 5 . táblázat tartalmazza.

${ }^{3}$ A szignifikancia szintet a teljes tanulmányban 5\%-ban határoztuk meg.

\section{Felhasznált irodalom}

Adam, S. (2002): A model of Web use in direct and online marketing strategy. Electronic Markets, Vol. 12, p. 1-8. dx.doi.org/10.1080/101967802762553521

Anderson, R. E. - Srinivasan, S. S. (2003): E-Satisfaction and E-Loyalty: A Contingency Framework. Psychology \& Marketing, Vol. 20, p. 123-138. dx.doi. org/10.1002/mar.10063

Arnett, D. B. - Laverie, D. A. - Meiers, A. (2003): Developing parsimonious retailer equity indexes using partial least squares analysis: A method and applications. Journal of Retailing, Vol. 79 No. 3, p. 161-170.

Babin, B. J. - Griffin, M. - Babin, L. (1994): The Effect of Motivation to Process on Consumers' Satisfaction Reactions. Advances in Consumer Research,Vol. 21, p. 406-411. http://acrwebsite.org/volumes/7626/volumes/v21/NA-21

Bauer, H. H. - Falk, T. - Hammerschmidt, M. (2006): eTransQual: A transaction process-based approach for capturing service quality in online shopping. Journal of Business Research, Vol. 59, p. 866-875. dx.doi.org/10.1016/j.jbusres.2006.01.021

Becker, J.-M. - Klein, K. - Wetzels, M. (2012): Hierarchical latent variable models in PLS-sem: Guidelines for using reflective-formative type models. Long Range Planning, Vol. 45 No. 5-6, p. 359-394.

Bressoles, G. - Nantel, J. (2004): Electronic Service Quality: A comparison of three measurement scales. Proceedings of 33th EMAC Conference, Murcia (Spain)

Bressolles, G. - Durrieu, F. - Giraud, M. (2007): The impact of electronic service quality's dimensions on customer satisfaction and buying impulse. Journal of Customer Behaviour, Vol. 6, p. 37-56. dx.doi.or$\mathrm{g} / 10.1362 / 147539207 X 198365$

Chang, H. H. - Wang, Y.-H. - Yang, W.-Y. (2009): The impact of e-service quality, customer satisfaction and loyalty on e-marketing: Moderating effect of perceived value. Total Quality Management \& Business Excellence, Vol. 20, p. 423-443. dx.doi. org/10.1080/14783360902781923

Chen, W. Ch. - Cheng, Ch. Y. (2012): How online and offline behavior processes affect each other: customer behavior in a cyber-enhanced bookstore. Qual Quant, Springer

Childers, T.L. - Carr, C.L. - Peck, J. -Carson, S. (2001): Hedonic and utilitarian motivations for online retail shopping behavior. Journal of Retailing, Vol. 77, p. 511. dx.doi.org/10.1016/S0022-4359(01)00056-2

Christodoulides, G. - Michaelidou, N. (2011): Shopping motives as antecedents of e-satisfaction and e-loyalty. Journal of Marketing Management, Vol. 27, p. 181197. dx.doi.org/10.1080/0267257X.2010.489815 
Cronin Jr., J. J. - Brady, M. K. - Hult, G. T. M. (2000): Assessing the Effects of Quality, Value, and Customer Satisfaction on Consumer Behavioral Intentions in Service Environments. Journal of Retailing,Vol. 76, p. 193. dx.doi.org/10.1016/S0022-4359(00)00028-2

Demeter, K. (2009): Szolgáltatások versenyképességének elemzése vállalati példák alapján. Magyar Minőség, Vol. 18, p. 6-18.

Eszes, I. (2011): A szóbeszéd marketing alkalmazási lehetőségeinek kiterjesztése a web kettes virtuális közösségekben. A Magyar Marketing Szövetség Marketing Oktatók Klubja 17. Országos Konferenciája, Pécsi Tudományegyetem, Pécs, 2011.augusztus 2930.

Fassnacht, M. - Köse, I. (2007): Consequences of Web-based service quality: Uncovering a multi-faceted chain of effects. Journal of Interactive Marketing (John Wiley \& Sons), Vol. 21, p. 35-54., dx.doi. org/10.1002/dir.20084

Francis, J. E. - White, L. (2002): Pirqual: a scale for measuring customer expectations and perceptions of quality in internet retailing. Presented at the AMA Winter Educators' Conference Proceedings, p. 263.

Francis, J. E. - White, L. (2003): Utilitarian and hedonic value across fulfillment product categories of Internet shopping. AMA ServSIG Services Research Conference 2003. Chicago: American Marketing Association..

Francis, J. E. - White, L. (2004): Value across fulfillment-product categories of Internet shopping,Managing Service Quality, Vol. 14, p. 226-234.

Francis, J. E. (2009): Category-specific RECIPEs for internet retailing quality. Journal of Services Marketing, Vol. 23, p. 450-461. dx.doi. org $/ 10.1108 / 08876040910995248$

Fu-Ling, H. - Chao Chao, C. (2012): A study of the relationship between the value perception and loyalty intention toward an e-retailer website. Journal of Internet Banking \& Commerce, Vol. 17, p. 1-18.

Gefen, D. (2002): Customer loyalty in e-commerce. Journal of the Association for Information Systems, Vol. 3, p. 27-51.

Gyulavári, T. (2005): Fogyasztói árelfogadás az interneten. Ph.D-értekezés. Budapest: Budapesti Corvinus Egyetem

Ha, H.-Y. - Muthaly, S. K. - Akamavi, R. K. (2010): Alternative explanations of online repurchasing behavioral intentions: A comparison study of Korean and UK young customers. European Journal of Marketing, Vol. 44, p. 874-904. dx.doi. org/10.1108/03090561011032757

Hair, J. (2003): Market research colloquium. 2013. szeptember, Zágráb, Horvátország

Hennig-Thurau, T. - Gwinner, K.P. - Walsh, G.-Grem- ler, D. D. (2004): Electronic word-of-mouth via consumer opinion platforms: What motivates consumers to articulate themselves on the internet? Journal of Interactive Marketing, Vol 18, No. 1, p. 38-52.

Henseler, J. - Ringle, C. M. - Sarstedt, M. (2016): Testing measurement invariance of composites using partial least squares. International Marketing Review, Vol. 33, No. 3.

Hirschman, E. C. - Holbrook, M. B. (1982): Hedonic Consumption: Emerging Concepts, Methods and Propositions. Journal of Marketing, Vol. 46, p. 92101.

Hsu, Sh.H.- Chen, W. H. - Hsieh, M.J. (2006): Robustness testing of PLS, LISREL, EQS and ANN-based SEM for measuring customer satisfaction. Total Quality Management \& Business Excellence, Vol. 17, p. 355-371. dx.doi.org/10.1080/14783360500451465

Hung, K. H. - Li, S. Y. (2007): The influence of eWOM on virtual consumer communities: social capital, consumer learning, and behavioral outcomes. Journal of Advertising Research, Vol.47, No. 4, p. 485-495.

Karakaya, F. - Barnes, N. G. (2010): Impact of online reviews of customer care experience on brand or company selection. Journal of Consumer Marketing, Vol. 27, No. 5, p. 447-457.

Kemény I. (2015): A versenytársak csak egy kattintásra vannak: Az újravásárlási és továbbajánlási szándék alakulása különböző e-kereskedelmi kategóriákban. Ph.D-értkezés. Budapest: Budapesti Corvinus Egyetem

Kemény, I. - Simon, J. - Nagy, Á. - Szúcs, K. (2015): Consumer satisfaction and word-of-mouth in Electronic Commerce: a possible segmentation method. in: Henseler, J. - Ringle, Ch. - Roldán, J. L. - Cepeda, G. (2015): 2nd International Symposium on Partial Least Squares Path Modeling - The Conference for PLS Users. Sevilla, Spanyolország, 2015.06.162015.06.19. p. 15.

Kenesei, Zs. - Kolos, K. (2008): A hatékony panaszkezelés lehetőségei: kompenzáció és bocsánatkérés. Vezetéstudomány, Vol. 39, No. 5, p. 27-39.

Kenesei, Zs. - Kolos, K. (2007): Szolgáltatásmarketing és -menedzsment. Budapest: Alinea Kiadó

Kim, D. J. (2012): An investigation of the effect of online consumer trust on expectation, satisfaction, and post-expectation. Information Systsem and E-Business Management, Springer. dx.doi.org/10.1007/ s10257-010-0136-2

Kotler, Ph. - Keller, K. L. (2008): Marketingmenedzsment. Budapest: Akadémiai Kiadó

Ladhari, R. (2010): Developing e-service quality scales: A literature review. Journal of Retailing \& Consumer Services, Vol. 17, p. 464-477. dx.doi.org/10.1016/j. jretconser.2010.06.003 
Liu, C. - Arnett, K. P. (2000): Exploring the factors associated with web site success in the context of electronic commerce. Information \& Management, Vol. 38, p. 23-33. dx.doi.org/10.1016/S0378-7206(00)00049-5

Loiacono, E. T. - Watson, R. T. - Goodhue, D. L. (2007): WebQual: An Instrument for Consumer Evaluation of Web Sites. International Journal of Electronic Commerce,Vol. 11, p. 51-87.

Lu, J. - Wang, L. - Hayes, L. A. (2012): How do technology readiness, platform functionality and trust influence c2c user satisfaction. Journal of Electronic Commerce Research, Vol. 13, p. 50-69.

Markos-Kujbus, É. (2013): Mikor szólnak a fogyasztók a vállalatok érdekében? - Az online szájreklám a virtuális közösségekben. Tézistervezet. Budapest: Budapesti Corvinus Egyetem

Moon, S. Y. - Philip, G. C. - Moon, S. (2011): The Effects of Involvement on E-Satisfaction Models. Services Marketing Quarterly, Vol. 32, p. 332-342. dx.doi.org /10.1080/15332969.2011.606764

Nagy Á. A. - Kemény I. - Simon J. - Kiss V. (2015a): Az online szájreklám alapjául szolgáló magatartás és az elégedettség kapcsolata. Marketing és Menedzsment, Vol. 49. No. 4, p. 18-35.

Nagy Á. A. - Kemény I. - Szúcs K. - Simon J. (2015b): A kapcsolat szorosság és az észlelt hasonlóság szerepe az online véleményelfogadásban és véleményformálásban. Egyesület a Marketing Oktatásért és Kutatásért XXI. országos konferenciájának tanulmánykötete. Budapest, 2015. augusztus 27-28. Budapest, Magyarország, p. 37.

Oliver, R. L. - DeSarbo, W. S. (1988): Response Determinants in Satisfaction Judgments. Journal of Consumer Research, Vol. 14, p. 495-507. dx.doi. org/10.2307/2489156

Oliver, R. L. (1980): A Cognitive Model of the Antecedents and Consequences of Satisfaction Decisions. Journal of Marketing Research, Vol. 17, p. 460-469. dx.doi.org/10.2307/3150499

Oliver, R. L. (1999): Whence Consumer Loyalty? Journal of Marketing, Vol. 63, p. 33-44. dx.doi. org/10.2307/1252099

Overby, J. W. - Lee, E.-J. (2006): The effects of utilitarian and hedonic online shopping value on consumer preference and intentions. Journal of Business Research, Vol. 59, p. 1160-1166. dx.doi.org/10.1016/j. jbusres.2006.03.008

Parasuraman, A. - Grewal, D. (2000): Serving Customers and Consumers Effectively in the Twenty-First Century: A Conceptual Framework and Overview. Journal of the Academy of Marketing Science, Vol. 28, p. 9. dx.doi.org/10.1177/0092070300281001

Parasuraman, A. - Zeithaml, V.A. - Berry, L. L. (1994): Reassessment of Expectations as a Comparison Stan- dard in Measuring Service Quality: Implications for Further Research. Journal of Marketing, Vol. 58, p. 111-124. dx.doi.org/10.2307/1252255

Park, D. - Kim, S. (2008): The effects of consumer knowledge on message processing of electronic word-of-mouth via online consumer reviews. Electronic Commerce Research and Applications, Vol 7, No. 4, p. 399-410.

Petre, M. - Minocha, S. - Roberts, D. (2006): Usability beyond the website: an empirically-grounded e-commerce evaluation instrument for the total customer experience. Behaviour \& Information Technology, Vol. 25, p. 189-203. dx.doi. org/10.1080/01449290500331198

Reichheld, F. F. - Schefter, P. (2000): E-loyalty your secret weapon on the web. Harvard Business Review, Vol.78, p. 105-113.

Rekettye, G. (1997): Az árak és a fogyasztói magatartás. Marketing \& Management, Vol 31, p. 25-31.

Santos, J. (2003): E-service quality: a model of virtual service quality dimensions. Managing Service Quality, Vol.13, p. 233-246. dx.doi. org/10.1108/09604520310476490

Sousa, R. - Voss, C. A. (2006): Service Quality in Multichannel Services Employing Virtual Channels. Journal of Service Research, Vol. 8, p. 356-371. dx.doi. org/10.1177/1094670506286324

Steffes, E. M. - Burgee, L. E. (2009): Social ties and online word of mouth. Internet Research, Vol.19, No. 1.

Szymanski, D. M. - Hise, R. T. (2000): e-Satisfaction: An Initial Examination. Journal of Retailing, Vol.76, p. 309-322. dx.doi.org/10.1016/S00224359(00)00035-X

van Riel, A. C. R. - Henseler, J. - Kemény, I. - Sasovova, Z. (2017): Estimating hierarchical constructs using consistent partial least squares: The case of second-order composites of common factors. Industrial Management \& Data Systems, Vol. 117, No. 1 , in print.

Wolfinbarger, M. - Gilly, M. C. (2003): eTailQ: dimensionalizing, measuring and predicting etail quality. Journal of Retailing, Vol. 79, p. 183-198. dx.doi. org/10.1016/S0022-4359(03)00034-4

Yoo, B. - Donthu, N. (2001): Developing a scale to measure the preceived quality of an internet shopping site: SITEQUAL. Quarterly Journal of Electronic Commerce, p. 1 - 19.

Zeithaml, V.A. - Parasuraman, A. - Malhotra, A. (2002): Service Quality Delivery Through Web Sites: A Critical Review of Extant Knowledge. Journal of the Academy of Marketing Science, Vol.30, p. 362-375. dx.doi.org/10.1177/009207002236911 
A szegmensek közötti különbségek értékelése

\begin{tabular}{|c|c|c|c|c|c|c|}
\hline \multirow{2}{*}{ Változó } & \multirow{2}{*}{$\mathbf{A}$} & \multirow{2}{*}{$\mathbf{B}$} & \multirow{2}{*}{$\begin{array}{c}\text { Különbség } \\
\text { (A-B) }\end{array}$} & \multirow{2}{*}{$\begin{array}{l}\text { Szig } \\
5 \%\end{array}$} & \multicolumn{2}{|c|}{ Küszöbértékek } \\
\hline & & & & & $2.5 \%$ & $97.5 \%$ \\
\hline \multirow{6}{*}{$\begin{array}{c}\text { Konkrét } \\
\text { honlaphoz } \\
\text { köthető minőség }\end{array}$} & \multirow{3}{*}{ Elégedett } & Kockázatcsökkentők & $1,033^{*}$ & ,000 & ,730 & 1,336 \\
\hline & & Online felületet és támogatást értékelők &, 135 & 403 &,- 183 &, 452 \\
\hline & & Elégedetlen & $1,667^{*}$ &, 000 & 1,391 & 1,943 \\
\hline & \multirow{2}{*}{ Kockázatcsökkentők } & Online felületet és támogatást értékelők &,$- 898^{*}$ &, 000 & $-1,261$ &,- 535 \\
\hline & & Elégedetlen &, $635^{*}$ &, 000 & ,307 & ,962 \\
\hline & $\begin{array}{l}\text { Online felületet és támogatást } \\
\text { értékelők }\end{array}$ & Elégedetlen & $1,532^{*}$ &, 000 & 1,192 & 1,873 \\
\hline \multirow{6}{*}{ Ügyfél-szolgálat } & \multirow{3}{*}{ Elégedett } & Kockázatcsökkentők &, $302^{*}$ & ,037 & 018 & ,586 \\
\hline & & Online felületet és támogatást értékelők & ,204 &, 178 &,- 094 &, 501 \\
\hline & & Elégedetlen & $1,818^{*}$ &, 000 & 1,559 & 2,077 \\
\hline & \multirow{2}{*}{ Kockázatcsökkentők } & Online felületet és támogatást értékelők &,- 098 &, 569 &,- 439 &, 242 \\
\hline & & Elégedetlen & $1,516^{*}$ &, 000 & 1,209 & 1,823 \\
\hline & $\begin{array}{c}\text { Online felületet és támogatást } \\
\text { értékelők }\end{array}$ & Elégedetlen & $1,614^{*}$ &, 000 & 1,295 & 1,934 \\
\hline \multirow{6}{*}{ Biztonság } & \multirow{3}{*}{ Elégedett } & Kockázatcsökkentők &, $597^{*}$ &, 000 & ,312 &, 882 \\
\hline & & Online felületet és támogatást értékelők & $887^{*}$ &, 000 &, 588 & 1,185 \\
\hline & & Elégedetlen & $1,890^{*}$ & ,000 & 1,631 & 2,150 \\
\hline & \multirow{2}{*}{ Kockázatcsökkentők } & Online felületet és támogatást értékelők & ,290 & ,096 &,- 052 &, 631 \\
\hline & & Elégedetlen & $1,293^{*}$ & 000 &, 985 & 1,602 \\
\hline & $\begin{array}{c}\text { Online felületet és támogatást } \\
\text { értékelők }\end{array}$ & Elégedetlen & $1,004^{*}$ & 000 &, 683 & 1,324 \\
\hline \multirow{6}{*}{ SAT } & \multirow{3}{*}{ Elégedett } & Kockázatcsökkentők & ,582* &, 000 & ,266 & ,899 \\
\hline & & Online felületet és támogatást értékelők &, 085 & ,612 &,- 246 & ,416 \\
\hline & & Elégedetlen & $1,639^{*}$ & 000 & 1,351 & 1,927 \\
\hline & \multirow{2}{*}{ Kockázatcsökkentők } & Online felületet és támogatást értékelők &,$- 497^{*}$ &, 010 &,- 876 &,- 118 \\
\hline & & Elégedetlen & $1,057^{*}$ &, 000 &, 715 & 1,399 \\
\hline & $\begin{array}{c}\text { Online felületet és támogatást } \\
\text { értékelők }\end{array}$ & Elégedetlen & $1,554^{*}$ & 000 & 1,198 & 1,909 \\
\hline \multirow{6}{*}{$\begin{array}{c}\text { Hagyományos } \\
\text { továbbajánlás } \\
\text { (WOM) }\end{array}$} & \multirow{3}{*}{ Elégedett } & Kockázatcsökkentők & ,636 &, 000 & ,313 & ,960 \\
\hline & & Online felületet és támogatást értékelők & ,298 &, 084 &,- 040 & ,637 \\
\hline & & Elégedetlen & $1,641^{*}$ &, 000 & 1,347 & 1,936 \\
\hline & \multirow{2}{*}{ Kockázatcsökkentők } & Online felületet és támogatást értékelők &,- 338 & 087 &,- 726 &, 049 \\
\hline & & Elégedetlen & $1,005^{*}$ &, 000 &, 655 & 1,355 \\
\hline & $\begin{array}{c}\text { Online felületet és támogatást } \\
\text { értékelők }\end{array}$ & Elégedetlen & $1,343^{*}$ &, 000 & 979 & 1,707 \\
\hline \multirow{6}{*}{$\begin{array}{l}\text { Újravásárlási } \\
\text { szándék }\end{array}$} & \multirow{3}{*}{ Elégedett } & Kockázatcsökkentők & ,488* &, 013 &, 106 & ,871 \\
\hline & & Online felületet és támogatást értékelők &, 071 &, 725 &,- 329 & ,472 \\
\hline & & Elégedetlen & $1,105^{*}$ &, 000 &, 757 & 1,454 \\
\hline & \multirow{2}{*}{ Kockázatcsökkentők } & Online felületet és támogatást értékelők &,- 417 & 074 &,- 875 & ,041 \\
\hline & & Elégedetlen & ,617 & ,004 & 204 & 1,031 \\
\hline & $\begin{array}{c}\text { Online felületet és támogatást } \\
\text { értékelők }\end{array}$ & Elégedetlen & $1,034^{*}$ & ,000 & 604 & 1,464 \\
\hline & & Kockázatcsökkentők &, $580^{*}$ &, 005 & ,177 & ,982 \\
\hline & Elégedett & Online felületet és támogatást értékelők &,- 153 & ,474 &,- 574 & ,268 \\
\hline & & Elégedetlen & ,708* &, 000 & ,341 & 1,074 \\
\hline$(\mathrm{e}-\mathrm{WOM})$ & Kockázatcsökkentők & Online felületet és támogatást értékelők &,$- 733^{*}$ & ,003 & $-1,215$ &,- 251 \\
\hline & & Elégedetlen & ,128 &, 562 &,- 307 &, 563 \\
\hline & $\begin{array}{c}\text { Online felületet és támogatást } \\
\text { értékelők }\end{array}$ & Elégedetlen &, $861^{*}$ & ,000 & ,408 & 1,313 \\
\hline
\end{tabular}

